\title{
Role of physical forcings and nutrient availability on the control of satellite-based chlorophyll $a$ concentration in the coastal upwelling area of the Sicilian Channel
}

\author{
BERNARDO PATTI ${ }^{1}$, CÁSTOR GUISANDE $^{2}$, ANGELO BONANNO $^{1}$, \\ GUALTIERO BASILONE $^{1}$, ANGELA CUTTITTA ${ }^{1}$ and SALVATORE MAZZOLA ${ }^{1}$ \\ ${ }^{1}$ Istituto per l'Ambiente Marino Costiero, Consiglio Nazionale delle Ricerche, Sede di Capo Granitola, via del Mare 3, \\ 91021 Campobello di Mazara (TP), Italy. E-mail: bernardo.patti@cnr.it \\ ${ }^{2}$ Facultad de Ciencias, Campus Universitario Lagoas-Marcosende, Universidad de Vigo, 36310-Vigo, Spain.
}

SUMMARY: The northern sector of the Sicilian Channel is an area of favourable upwelling winds, which ought to support primary production. However, the values for primary production are low when compared with other Mediterranean areas and very low compared with the most biologically productive regions of the world's oceans: California, the Canary Islands, Humboldt and Benguela. The aim of this study was to identify the main factors that limit phytoplankton biomass in the Sicilian Channel and modulate its monthly changes. We compared satellite-based estimates of chlorophyll $a$ concentration in the Strait of Sicily with those observed in the four Eastern Boundary Upwelling Systems mentioned above and in other Mediterranean wind-induced coastal upwelling systems (the Alboran Sea, the Gulf of Lions and the Aegean Sea). Our results show that this low level of chlorophyll is mainly due to the low nutrient level in surface and sub-surface waters, independently of wind-induced upwelling intensity. Further, monthly changes in chlorophyll are mainly driven by the mixing of water column and wind-induced and/or circulation-related upwelling processes. Finally, primary production limitation due to the enhanced stratification processes resulting from the general warming trend of Mediterranean waters is not active over most of the coastal upwelling area off the southern Sicilian coast.

Keywords: upwelling, Ekman transport, nutrients, chlorophyll $a$, Mediterranean Sea, Sicilian Channel.

RESUMEN: IMPORTANCIA DE LOS FENÓMENOS FÍSICOS Y LA DISPONIBILIDAD DE NUTRIENTES EN EL CONTROL DE LA CONCENTRACIÓN DE CLOROFILA ESTIMADA POR SATÉLITE EN EL ÁREA COSTERA DE AFLORAMIENTO DEL CANAL DE SiCILIA. - El sector norte del Canal de Sicilia es un área de vientos favorables para el afloramiento, lo cual debe favorecer la producción primaria. Sin embargo, los valores de producción primaria son bajos comparados con otras áreas del Mediterráneo y muy bajos comparados con las regiones biológicamente más productivas de los océanos a nivel mundial: California, Canarias, Humboldt y Benguela. El objetivo de este estudio fue identificar los principales factores que limitan la biomasa del fitoplancton y modulan sus cambios mensuales. Comparamos estimas de la concentración de clorofila $a$ basadas en satélite en el estrecho de Sicilia, con las observadas en los cuatro sistemas orientales de afloramiento mencionados anteriormente y en otros sistemas costeros del Mediterráneo en los que el viento favorece los afloramientos (Mar del Alborán, Golfo de León y Mar Egeo). Nuestros resultados muestran que la baja producción primaria es debida principalmente a la baja entrada de nutrientes en aguas superficiales, independientemente de la intensidad del afloramiento causado por el viento. Por otro lado, los cambios mensuales en la producción primaria se deben a la mezcla de la columna de agua y afloramientos asociados al viento y/o procesos de circulación en la zona. Finalmente, la limitación de la producción primaria debida al aumento del proceso de estratificación resultante de la tendencia general de calentamiento de las aguas del Mediterráneo, no es activa a lo largo de la mayor parte del área de afloramiento en la costa sur de Sicilia.

Palabras clave: afloramiento, transporte de Ekman, nutrientes, clorofila a, mar Mediterráneo, Canal de Sicilia. 


\section{INTRODUCTION}

The production of fished pelagic species in different regions depends on the phytoplankton primary production, the length of food chains, and the transfer efficiency (Jennings et al., 2001). In ecosystems with similar food chains and sources of primary production, there are good correlations between fish yields and primary production (Iverson, 1990). Basilone et al. (2004) showed that a high proportion of the variance of anchovy growth between areas was explained mainly by changes in the chlorophyll concentration, and that the growth of the anchovy (along with phytoplankton biomass) in the Sicilian channel was at the low end of the range. Therefore, phytoplankton biomass and related primary production are clearly low in the Sicilian Channel and the best indication of this low productivity is this limited fish production. The question is, what is it that limits primary production in the Sicilian Channel?

Most of the studies about the identification of the factors controlling primary (and secondary) production have been carried out in the most biologically productive regions of the world's oceans: California, Canary, Humboldt, and Benguela (Ware, 1992; Thomas et al., 1994; Carr, 2002; Carr and Kearns, 2003; Hardman-Mountford et al., 2003; Thomas et al., 2004; Ribeiro et al., 2005; Patti et al., 2008; Rykaczewski and Checkley, 2008; Demarcq, 2009), probably because these areas support large commercial fisheries. Less attention has been paid to the identification of the factors controlling primary production in areas with low productivity, in particular in coastal upwelling systems of the Mediterranean Sea.

Patti et al. (2008) demonstrated that the high chlorophyll $a$ (Chl a) concentration, and also the differences in Chl $a$ among the most biologically productive Eastern Boundary Upwelling System (EBUS) regions of California, Canary, Humboldt, and Benguela are mainly due to the extension of the continental shelf, nutrient concentration, turbulence in the mixed layer and, lastly, offshore Ekman transport. Now that the main factors affecting primary production in the major upwelling areas have been identified, it may help to identify the factors controlling primary production in low productivity areas, such as the Mediterranean Sea. In this paper we used satellite-based Chl $a$ estimates as it has been demonstrated that they are good proxies for primary production data (Joint and Groom, 2000). We therefore consider that the differences in chlorophyll concentration among areas observed also indicate differences in primary production.

The Mediterranean is characterized by oligotrophic conditions and it has been suggested that there is a decreasing trend over time in chlorophyll concentration. This has been associated with increased nutrient limitation resulting from reduced vertical mixing due to a more stable stratification of the basin, in line with the general warming of the Mediterranean (Barale et al., 2008). Behrenfeld et al. (2006) also suggested that the decreasing trend in ocean primary production is due to climatic changes that lead to surface warming, resulting in an increase in the density contrast between the surface layer and underlying nutrient-rich waters. This in turn leads to enhanced stratification, which suppresses nutrient exchange through vertical mixing. Global warming should therefore lead to a decrease in primary production in the Mediterranean.

However, the Mediterranean Sea shows considerable spatial heterogeneity in primary production (Estrada, 1996; Crispi and Pacciaroni, 2009). Therefore, it would be interesting to determine whether this potential limitation of primary production due to the more stable stratification of the basin that is suggested to be the case for the Mediterranean (Barale et al., 2008) is also observed in the upwelling area that characterizes the northern sector of the Strait of Sicily, an area very important for the nutrient concentrations encountered in Mediterranean waters (Karafistan et al., 2002).

Using a comparative approach, this study aimed to use satellite-based phytoplankton biomass estimates to identify the factors limiting primary production off the southern coast of Sicily and modulating its monthly changes.

\section{MATERIALS AND METHODS}

\section{Study area}

This study is mainly based on in situ and satellite environmental information available for the period September 1997 to December 2007 for each of the sites shown in Figure 1, representing some of the most important coastal upwelling systems of the Mediterranean Sea (Alboran Sea, Gulf of Lions, Sicilian Channel, and Aegean Sea). Information on turbulence (see the section "Wind-mixing index" below) was gathered during the period September 1997 to May 2007, whereas information about nutrients covers a wider time span (see the section "Nutrients" below). Average data values over $1^{\circ} \times 1^{\circ}$ of latitude and longitude cells were employed for all factors.

Although some of the data sets used in this study are accessible on the Internet at higher resolutions, $1^{\circ} \times$ $1^{\circ}$ resolution was chosen in order to meet the available spatial resolution of the International Comprehensive Ocean-Atmosphere Data Set (I-COADS) (turbulence data) and the World Ocean Atlas 2005 (WOA05) data sets (nutrients data). Box locations of $1^{\circ} \times 1^{\circ}$ were selected by choosing those sites closest to the coast and better able to represent the features of the local upwelling system (Fig. 2). Cross-correlation analysis (see the section "Statistical analysis" below) is only based on monthly time series extracted from sites located off the southern coast of Sicily.

For comparison purposes, satellite-based chlorophyll $a$ estimates, and other in situ environmental information (average Ekman transport, Ekman transport variability, macronutrients) for a series of alongshore $1^{\circ}$ $\times 1^{\circ}$ boxes located in the main world Eastern Boundary 

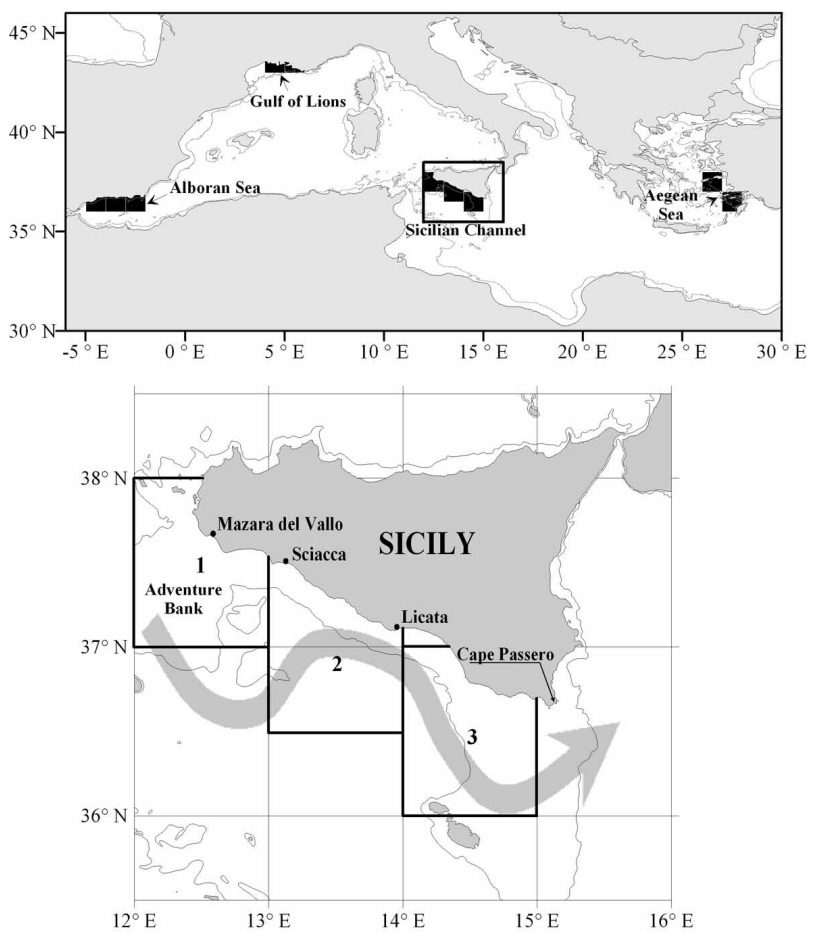

FIG. 1. - Map showing the $1^{\circ} \times 1^{\circ}$ of latitude and longitude boxes in the selected Mediterranean upwelling regions (Alboran Sea, Gulf of Lions, Sicilian Channel, and Aegean Sea), where Chl $a$ concentration, Ekman transport, wind mixing, nutrient concentration, and water column stability were estimated or extracted from the available databases. The Sicilian Channel area, which time series crosscorrelation analysis is based on, is evidenced below. The average path of the Atlantic Ionian Stream (AIS) over the Sicily Channel area and $200 \mathrm{~m}$ isobath are superimposed.

Upwelling Systems (EBUS; the locations are the same as those adopted by Patti et al., 2008) were also used.

\section{Wind stress and offshore Ekman transport}

Global marine monthly summaries of the observations from the International Comprehensive Ocean Atmosphere Data Set (I-COADS), as available in the

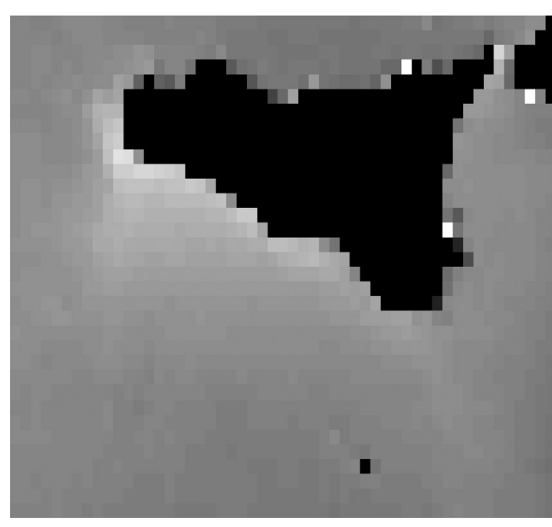

a
Data Support Section of the University Corporation for Atmospheric Research (UCAR) website (http://dss. ucar.edu/datasets/ds540.1/), were used to calculate average climatological patterns over the $1^{\circ} \times 1^{\circ}$ boxes of Figure 1 and to produce the wind stress/Ekman transport field shown in Figure 3. Computations of the zonal and meridional Ekman transport components involved the calculation of wind stress $\tau_{x}$ and $\tau_{y}$ values starting from the monthly mean values of zonal (WU) and meridional (WV) components of "pseudo wind stress" $\left(\mathrm{m}^{2} \mathrm{~s}^{-2}\right)$ contained in group 5 of the Monthly Summary Groups (MSG), using the following equations:

$$
\tau_{x}=\rho_{a} C_{d} W U \quad \tau_{y}=\rho_{a} C_{d} W V
$$

where $\rho_{a}=1.2 \mathrm{~kg} \mathrm{~m}^{-3}$ (air density), $C_{d}=1.410^{-3}$ (drag coefficient), and $W U$ and $W V$ are the MSG summaries for wind stress parameters.

Ekman transport components were calculated according to Bakun (1973):

$$
Q_{x}=\frac{\tau_{y}}{f \rho} 1000 \quad Q_{y}=\frac{-\tau_{x}}{f \rho} 1000
$$

where $Q_{x}$ and $Q_{y}$ are Ekman transport along the $\mathrm{x}$ (zonal) and y (meridional) axes, respectively, in $\mathrm{m}^{3} \mathrm{~s}^{-1}$ $\mathrm{km}^{-1}, \rho=1025 \mathrm{~kg} \mathrm{~m}^{-3}$ (water density), $f$ is the (latitudedependent) Coriolis factor in $\mathrm{s}^{-1}$, and $\tau_{x}$ and $\tau_{y}$ are the wind stress components (in $\mathrm{N} \mathrm{m}^{-2}$, i.e. kilogram metre $^{-1}$ second $^{-2}$ ) over the sea.

Estimates of standard errors of Ekman transport components were obtained using standard statistical formulation for the variance of random variables applied to the available information on mean and standard deviation of wind stress monthly summaries.

Data consistency over the coastal regions of the selected upwelling systems is evident, as wind stress/ Ekman transport vectors maintain approximately the same direction (Fig. 3). In particular, it is worth noting that the resultant vectors of $Q_{x}$ and $Q_{y}$ components, herein used as an index of wind-induced alongshore

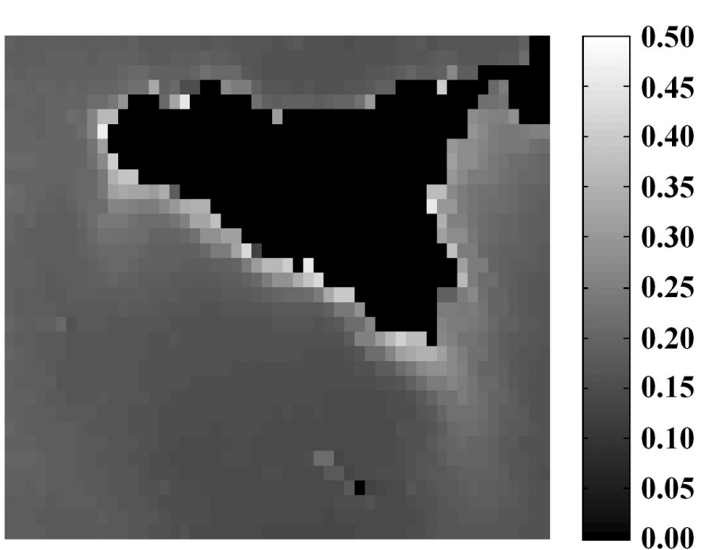

b

FIG. 2. - Climatologies of: (a) SST (degree C), and (b) Chl $a$ concentration ( $\mathrm{mg} \mathrm{m}^{-3}$ ) over the study area, obtained respectively from the AQUA MODIS mission (period: January 2002 - February 2008) and the SeaWiFS mission (period: September 1997 to December 2007). 


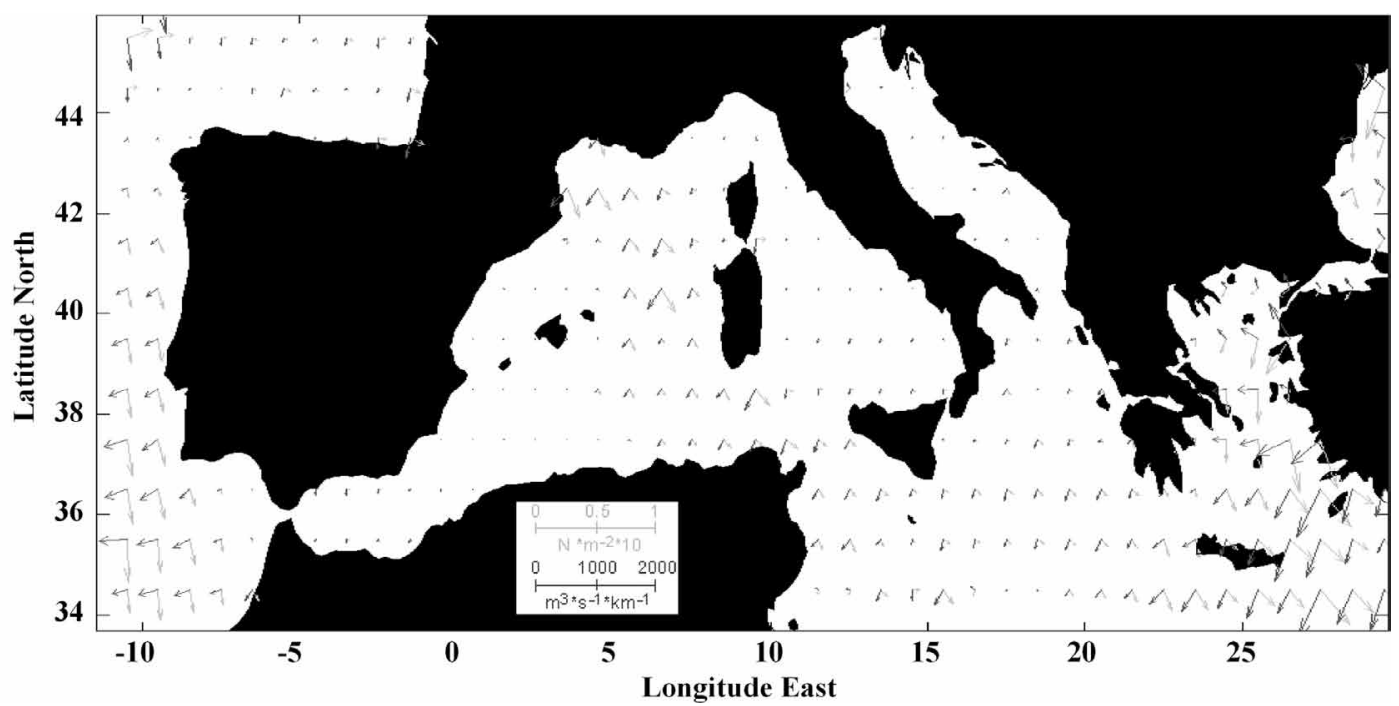

FIG. 3. - Resultant vectors of $Q x$ and $Q y$ Ekman transport (dark grey arrows) and $\tau_{x}$ and $\tau_{y}$ wind stress (light grey arrows) over the western Mediterranean Sea and near North Atlantic Ocean. Vectors represent the climatological averages of COADS monthly summaries covering the period 1998-2007.

upwelling intensity, are approximately perpendicular to the shoreline.

Due to the COADS data scarcity in the $1^{\circ} \times 1^{\circ}$ boxes off the southern Sicilian coast, which led to the presence of some missing monthly values, for the aims of time series analysis another source of information was used instead, namely the Simple Ocean Data Assimilation (SODA) database. Specifically, monthly Ekman transport values over the period considered (September 1997 to December 2007) and the related climatologies were obtained from monthly zonal wind stress data, accessible at $0.5^{\circ}$ resolution, by assimilating the available field observations (http://ingrid.ldeo. columbia.edu/SOURCES/.CARTON-GIESE/.SODA/. v2p0p2-4/; Carton et al., 2000).

\section{Nutrients}

Data on monthly climatologies for nutrients (nitrate, phosphate, silicate) were obtained from the WOA05 database at $1^{\circ}$ resolution (Garcia et al., 2006), as implemented in Ocean Data View (ODV) format (Schlitzer, 2008).

For nutrients, this dataset assembles various sources of information spanning the period 1921-2004, although it is based mainly (in more than $95 \%$ of nutrient profiles) on bottle data from the World Ocean Database 2005 (WOD05; Boyer et al., 2006) collected later than 1960. Average concentrations in the mixed layer (from a depth range of 0 to $50 \mathrm{~m}$ ) were compared with concentrations below the pycnocline (depth range: 75-200 $\mathrm{m}$ ), representing the source water layer for nutrients in continental shelf areas.

\section{Chlorophyll- $a$ concentration}

Chl $a$ data used herein were obtained from the NASA Sea-Viewing Wide Field-of-View Sensor
(SeaWiFS) Project, distributed as a Level 3 Standard Mapped Image product (Feldman and McClain, 2006). Specifically, monthly composite images for the period September 1997 to December 2007 were downloaded from the http://oceancolor.gsfc.nasa.gov/cgi/l3 website in Hierarchical Data Format (HDF). These images have 2160 by 4320 pixels and a resolution of about $9 \times 9 \mathrm{~km}^{2}$. To match the resolution of I-COADS and WOA05, average pigment concentration values were obtained for each of the $1^{\circ} \times 1^{\circ}$ boxes in Figure 1 .

Monthly Chl $a$ estimates were also used for further time series correlation analysis, limited to the Strait of Sicily region.

\section{Wind-mixing index}

The energy transferred through the water column by the wind creates turbulence in the surface layers. Therefore, a wind-mixing index in the upper layer is usually calculated as the cube of wind speed. We used this index as an indicator of turbulence in the surface layers. Wind speed data from September 1997 to May 2007 for wind-mixing index calculation were extracted from the Global Marine Monthly Summaries in the ICOADS data set.

\section{Sea surface temperature}

Monthly $1^{\circ} \times 1^{\circ}$ (spatial resolution) optimal interpolation (OI) sea surface temperature (SST) data (Reynolds et al., 2002) used for this study were provided by the NOAA Operational Model Archive Distribution System from their website http://nomad3.ncep.noaa. gov/ncep_data/index.html. From the global data set, covering the period November 1981 to the present, we extracted SST time series for the $1^{\circ} \times 1^{\circ}$ boxes located along the southern Sicilian coast (Fig. 1).

Further SST data, downloaded from http://oceancolor.gsfc.nasa.gov/cgi/13 and used for the mapping of 
the climatological SST field over the Sicilian channel, were taken from the AQUA MODIS mission, spanning the period January 2002 to February 2008.

\section{Water column stability}

Water column stability was estimated using the methodology described by Guisande et al. (2001). Specifically, for each of the three sites in Figure 1 and for the period September 1997 to December 2007, monthly density values were calculated using temperature and salinity data extracted at the standard depths of $5,15,25,36$, and $47 \mathrm{~m}$ taken from the Simple Ocean Data Assimilation (SODA) (http://ingrid.ldeo. columbia.edu/SOURCES/.CARTON-GIESE/.SODA/. v2p0p2-4/) database (Carton et al., 2000). With the aim of detecting trends, the entire available time series, starting from January 1958, was also used.

The Brunt-Väisälä or buoyancy frequency equation $(N)$ was used to measure the strength of the density gradients:

$$
N=\sqrt{\frac{g}{\bar{\rho}} \frac{d \rho}{d z}}
$$

where $\rho$ is the density of the water (in $\mathrm{kg} \mathrm{m}^{-3}$ ), $\bar{\rho}$ is the mean $\rho$ of the water column, $g$ is the acceleration due to gravity, and $z$ is the depth. The integrated buoyancy frequency estimated using the trapezoid method was used as an indicator of stability of the water column $(S)$ :

$$
S=\frac{\int_{z_{1}}^{z_{n}} N d z}{\int_{z_{1}}^{z_{n}} d z}
$$

Low values of $S$ (presented as cycles $\mathrm{h}^{-1}$ ) indicate that the water column is mixed, whereas high values indicate that the water column is stratified.

\section{Statistical analysis}

Stepwise forward regression analysis was applied on average annual climatological data (Guisande et $a l ., 2006$ ), with the aim of identifying environmental factors able to affect $\mathrm{Chl} a$ concentration patterns in the selected Mediterranean sites. This analysis was performed using Statistica v. 6 (Statsoft, 2001).

Correlation analysis between environmental monthly time series was only performed for sites located in the Strait of Sicily. For each of these sites (see lower part of Fig. 1), Pearson correlation coefficients were calculated between each available monthly series of environmental factors (regressors: Ekman transport, SST, water column stability, and wind-mixing index) and Chl $a$ (regressand). Each series was firstly deseasonalized by subtracting from each monthly value the corresponding monthly average for the entire time series. In addition, as the deseasonalized anomalies so obtained were not in general trend-stationary, a linear trend was removed from all data prior to regression. For each model, correlation coefficients were computed and tested for significance at lags 0,1 , and 2, adopting Bonferroni correction (Miller, 1981). Accordingly, single significance levels obtained for each estimated correlation's coefficients were divided by the total number of models contemporarily tested, that is 4 (factors) $\times 3$ (boxes) $\times 3$ (lags) $=36$.

\section{RESULTS}

\section{Average annual and monthly climatological patterns}

The Chl $a$ concentrations off the southern Sicilian coast are extremely low compared with those of the main world EBUSs (Fig. 4a) and also with those of the other Mediterranean sites (Table 1), with the sole exception of the Aegean Sea, which exhibits even lower values. Observed distribution was quite homogeneous over the

TABLE 1. - Average annual climatological values of Chl $a$ concentration, Ekman transport, coefficient of Variation of Ekman transport, windmixing index from September 1997 to December 2007 (May 2007 for wind-mixing index only), and the mean values of nitrate, phosphate and silicate in the mixed layer waters $(0-50 \mathrm{~m})$ and in sub-surface waters $(75-200 \mathrm{~m})$, mainly obtained in the period from 1960 to 2004 in the $1^{\circ} \times 1^{\circ}$

\begin{tabular}{|c|c|c|c|c|c|c|c|c|c|c|c|c|}
\hline Region & Lat $\mathrm{N}$ & Long E & $\begin{array}{c}\text { Chl } a \\
\text { concentration } \\
\left(\text { box } 1^{\circ} \times 1^{\circ}\right) \\
{\left[\mathrm{mg} \mathrm{m}^{-3}\right]}\end{array}$ & $\begin{array}{c}\text { Ekman } \\
\text { transport } \\
{\left[\mathrm{m}^{3} \mathrm{~km}^{-1} \mathrm{~s}^{-1}\right]}\end{array}$ & $\begin{array}{l}\text { Coefficient } \\
\text { of variation } \\
\text { of Ekman } \\
\text { transport }\end{array}$ & $\begin{array}{l}\text { Wind- } \\
\text { mixing } \\
\text { index } \\
{\left[\mathrm{m}^{3} \mathrm{~s}^{-3}\right]}\end{array}$ & $\begin{array}{c}\mathrm{NO}_{3}^{-} \\
(0-50 \mathrm{~m}) \\
{\left[\mu \mathrm{mol} \mathrm{l}^{-1}\right]}\end{array}$ & $\begin{array}{c}\mathrm{PO}_{4}^{3-} \\
(0-50 \mathrm{~m}) \\
{\left[\mu \mathrm{mol} \mathrm{l}^{-1}\right]}\end{array}$ & $\begin{array}{c}\mathrm{SiO}_{4}^{-} \\
(0-50 \mathrm{~m}) \\
{\left[\mathrm{mmol} \mathrm{l}^{-1}\right]}\end{array}$ & $\begin{array}{c}\mathrm{NO}_{3}^{-} \\
(75-200 \mathrm{~m}) \\
{\left[\mu \mathrm{mol} \mathrm{l}^{-1}\right]}\end{array}$ & $\begin{array}{c}\mathrm{PO}_{4}^{3-} \\
(75-200 \mathrm{~m}) \\
{\left[\mu \mathrm{mol} \mathrm{l}^{-1}\right]}\end{array}$ & $\begin{array}{c}\mathrm{SiO}_{4}^{-} \\
(75-200 \mathrm{~m}) \\
{\left[\mu \mathrm{mol} \mathrm{l}^{-1}\right]}\end{array}$ \\
\hline Sicilian Channel & 37.5 & 12.5 & 0.22 & 379.9 & 4.40 & 720.7 & & & & & & \\
\hline Sicilian Channel & 37.0 & 13.5 & 0.19 & 467.8 & 3.74 & $749.6^{(\mathrm{a})}$ & $1.1^{(b)}$ & $0.1^{\text {(b) }}$ & $2.3^{(\mathrm{b})}$ & $1.8^{(b)}$ & $0.2^{\text {(b) }}$ & $2.5^{(\mathrm{b})}$ \\
\hline Sicilian Channel & 36.5 & 14.5 & 0.17 & 373.2 & 4.54 & 684.9 & & & & & & \\
\hline Gulf of Lions & 43.5 & 4.5 & 0.95 & 648.7 & 2.92 & 1384.5 & 1.9 & 0.2 & 1.7 & 4.2 & 0.2 & 2.3 \\
\hline Gulf of Lions & 43.5 & 5.5 & 0.40 & 586.5 & 3.36 & 923.8 & 2.1 & 0.3 & 1.7 & 4.1 & 0.3 & 2.3 \\
\hline Aegean Sea & 37.5 & 26.5 & 0.16 & 980.3 & 2.07 & 804.5 & 1.0 & 0.1 & 1.7 & 1.0 & 0.1 & 1.4 \\
\hline Aegean Sea & 36.5 & 27.5 & 0.14 & 1163.1 & 1.74 & 746.0 & 0.6 & 0.1 & 1.7 & 0.9 & 0.1 & 1.5 \\
\hline Alboran Sea & 36.5 & 355.5 & 0.65 & 309.4 & 5.72 & 619.8 & 3.8 & 0.2 & 3.3 & 5.1 & 0.3 & 4.9 \\
\hline Alboran Sea & 36.5 & 356.5 & 0.52 & 297.5 & 6.49 & 699.8 & 3.5 & 0.2 & 3.0 & 4.9 & 0.3 & 5.1 \\
\hline Alboran Sea & 36.5 & 357.5 & 0.41 & 209.0 & 9.15 & 693.0 & 3.0 & 0.2 & 2.6 & 5.0 & 0.3 & 5.0 \\
\hline
\end{tabular}
cells of Figure 1. Latitude and longitude represent the centre of a $1^{\circ} \times 1^{\circ}$ cell. See the section "Materials and Methods" for further explanations.

(a) Value corresponding to the COADS $1^{\circ} \times 1^{\circ}$ box centred on $36.5 \mathrm{~N}-13.5 \mathrm{E}$.

(b) Value corresponding to the WOA05 grid point $36.5 \mathrm{~N}-13.5 \mathrm{E}$. 

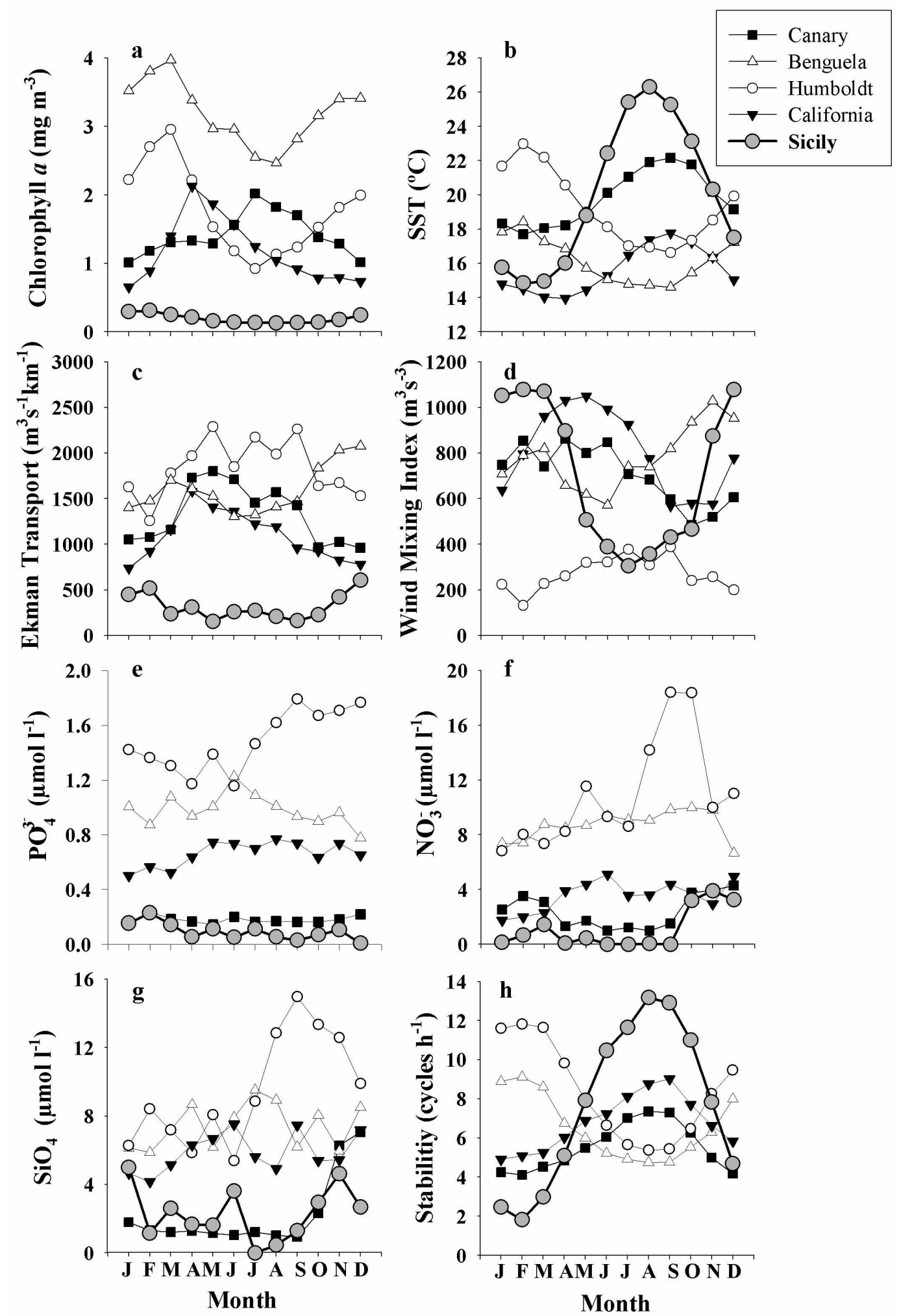

FIG. 4. - Mean monthly climatologies of: (a) Chl $a$, (b) sea surface temperature, (c) Ekman transport, (d) wind-mixing index, (e) phosphate concentration, (f) nitrate concentration, (g) silicate concentration, and (h) water column stability averaged over the three $1^{\circ} \times 1^{\circ}$ boxes off the southern Sicilian coast of Figure 1 (grey circles). Climatologies of the four main world EBUS regions (Canary, Benguela, Humboldt, and California), also displayed for comparative purposes, are from Patti et al. (2008). They refer to a set of $1^{\circ} \times 1^{\circ}$ boxes selected along the coast of the EBUS regions, with the following latitudinal extents: $21^{\circ} \mathrm{N}-36^{\circ} \mathrm{N}$ (Canary), $34^{\circ} \mathrm{S}-18^{\circ} \mathrm{S}$ (Benguela), $23^{\circ} \mathrm{S}-18^{\circ} \mathrm{S}$ (Humboldt), and $26^{\circ} \mathrm{N}-40^{\circ} \mathrm{N}$ (California). 
three $1^{\circ} \times 1^{\circ}$ cells located in the Sicilian channel, with a small eastward decrease (Table 1). The seasonal pattern was roughly reversed with respect to those of the EBUSs considered, with an increased Chl $a$ during the boreal autumn-winter (from September to March), corresponding to the austral spring-summer in the two southern hemisphere systems (Benguela and Humboldt).

Chl $a$ was also found to be in phase with the seasonal wind forcing, as already observed in the main EBUSs, the only exception being Humboldt (Patti et al., 2008). In fact, Ekman transport displayed higher values (more offshore transport and hence higher upwelling) from November to February (Fig. 4c).

For the wind-mixing index (Fig. 4d), the Sicilian channel region showed consistently low values in the summer (from June to September), comparable only with the Humboldt area, whereas in the other months of the year they were in the range observed for the other EBUS regions.

Nutrient content off the southern coast of Sicily was very low. Only the Canary region showed similar values for silicate, and partly phosphate, but nitrate concentration in Sicily was approximately half of the already very low levels observed in the Canary Islands (Figs. 4e, 4f, and 4g). The seasonal pattern, if any, was hard to detect from the analysis of available data, with the tentatively expressed exception of silicate, which appears to be in phase with upwelling intensity.

Stratification (Fig. 4h) showed quite a high range of fluctuation, reflecting the corresponding changes in temperature (see Fig. 4b). The observed seasonal pattern was in phase with those of the two northern hemisphere EBUS regions but, unlike in all the EBUS regions, including the southern hemisphere ones, in Sicily it was out of phase with the intra-annual fluctuations in Chl $a$. Actually, in the Sicilian Channel the highest Chl $a$ values were recorded during those periods of the year when the water was less stratified (low values of water column stability) (See Figs. $4 \mathrm{a}$ and $4 \mathrm{~h}$ ).

Figures 5, 6, 7 and 8 illustrate the position of the selected Mediterranean upwelling systems in the context of the four main most productive coastal marine areas, that is Canary Islands, Benguela, California, and Humboldt (data from Patti et al., 2008). Chlorophyll concentration, nutrients and Ekman transport levels in Sicilian waters are at the lowest end of the parameter ranges and, in addition, are consistent with the observed relationships among the variables. However, the positions of the other Mediterranean sites in Figure 5 clearly indicate that offshore transport is not able to explain the observed primary production levels (see also Fig. 9a below, showing Mediterranean sites only). In fact, at approximately the same level of wind forcing, the Alboran Sea and Gulf of Lions sites have Chl $a$ concentrations that are double those of the Sicilian Channel, whereas the quite strong Ekman transport experienced by the Aegean region is not able to produce Chl $a$ levels greater than those observed off the southern Sicilian coast. The relationship between the

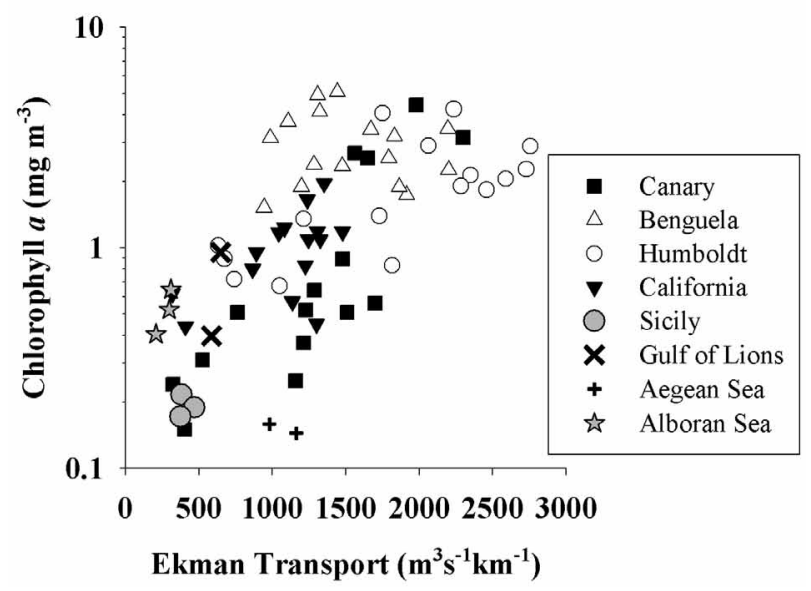

FIG. 5. - Relationship between climatological mean offshore Ekman transport and Chl $a$ concentration (in logarithmic scale). Mediterranean sites' data values are given in Table 1. Data on Canary, Benguela, Humboldt, and California EBUS regions from Patti et al. (2008).

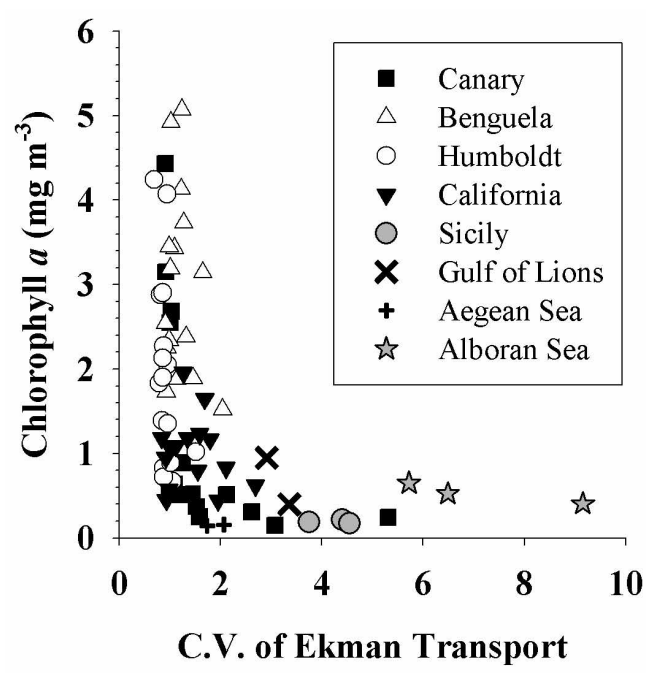

FIG. 6. - Relationship between coefficient of variation of mean annual Ekman transport and Chl $a$. Mediterranean sites' data values are given in Table 1. Data on Canary, Benguela, Humboldt, and California EBUS regions from Patti et al. (2008).

coefficient of variation (CV) of Ekman transport and the surface Chl $a$ concentrations, shown in Figure 6, also suggests a possible negative impact of variability patterns on phytoplankton biomass levels.

Nutrient availability clearly appears to be the main limiting factor for primary production in Sicilian waters and in all the selected Mediterranean sites (Figs. 7 and 8 ). The analysis of water masses above and below the pycnocline, on average approximately located at 40-50 m depth for all regions, gave further insight into the matter. With the only exception of phosphate, Chl $a$ values in the selected Mediterranean sites appear to be better explained by nutrient concentrations of water masses at depths $(75-200 \mathrm{~m})$ representing the "source" layer for the surface levels, where most of the production is concentrated (Fig. 9). Incidentally, this is not the 

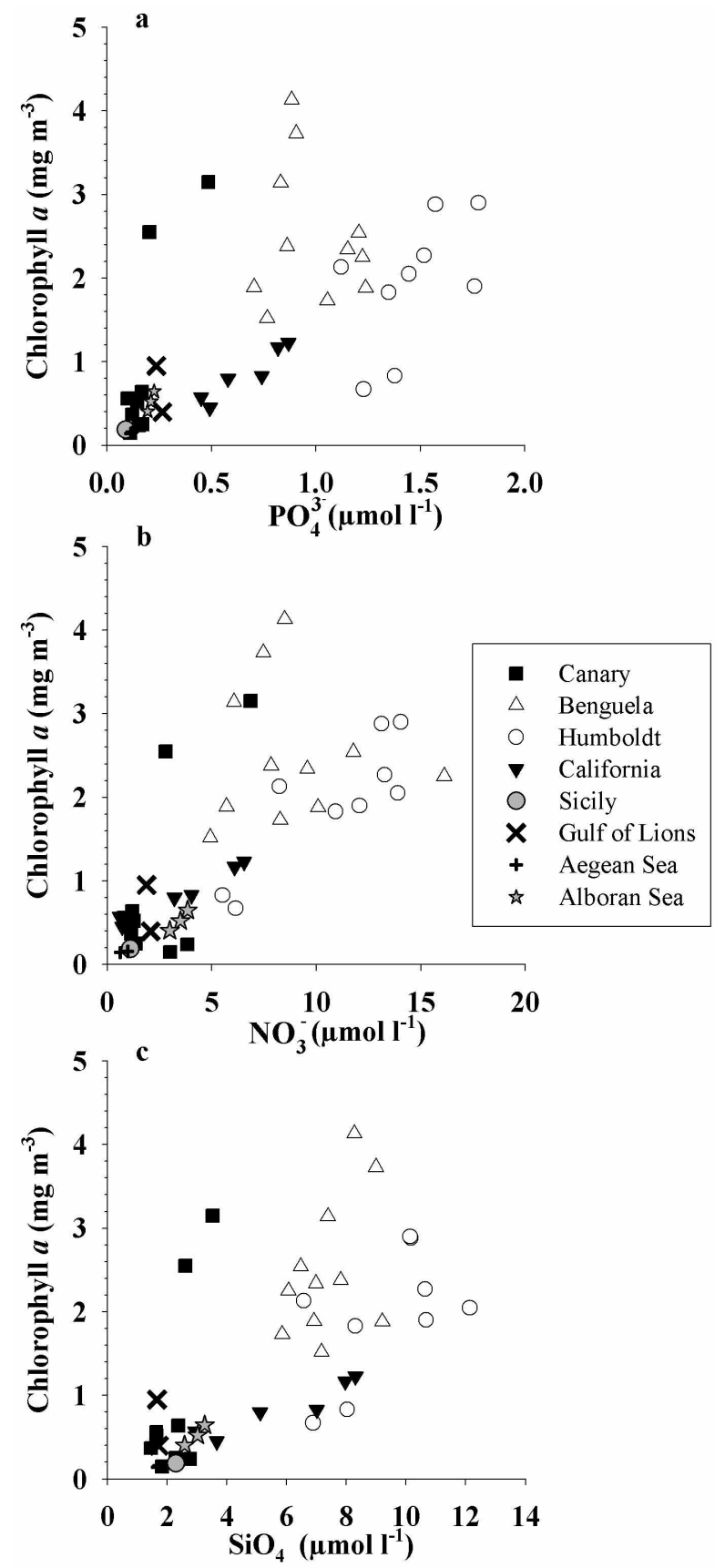

FIG. 7. - Relationships between mean annual phosphate (a), nitrate (b), and silicate (c) over the depth range 0-50 $\mathrm{m}$ and $\mathrm{Chl} a$. Mediterranean sites' data values are given in Table 1. Data on Canary, Benguela, Humboldt, and California EBUS regions from Patti et al. (2008).

case for most of the sites of the EBUS regions, which at depths greater than $50 \mathrm{~m}$ are also characterized by much higher concentration levels than the Mediterranean (not shown). In addition, it is worth noting that estimated $\mathrm{N}: \mathrm{P}$ ratios in surface waters and even over the layer (75-200m) are particularly low in the Sicilian Channel and the Aegean sea (see Table 1).

Although the number of observations is too low to obtain conclusive results, multiple linear regression
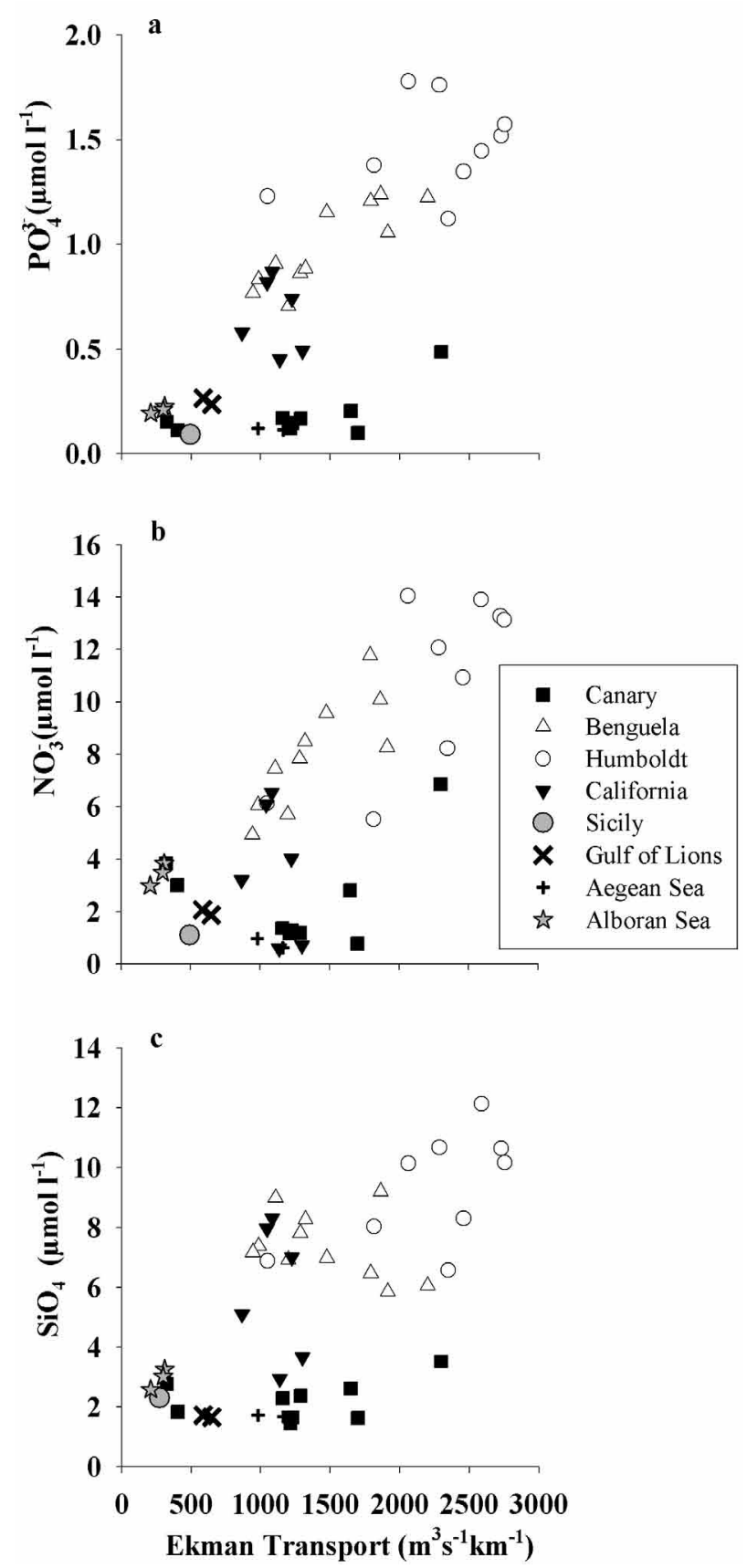

FIG. 8. - Relationships between mean annual phosphate (a), nitrate (b), and silicate (c) over the depth range 0-50 m and Ekman transport. Mediterranean site data values are given in Table 1. Data on the Canary Islands, Benguela, Humboldt, and California EBUS regions from Patti et al. (2008).

models were also fitted to the available data for the Mediterranean sites, using $\ln (\mathrm{Chl} a)$ as a regressand and Ekman transport, CV of Ekman transport, windmixing index and macronutrients (phosphate, nitrate, and silicate) as regressors, with a backward stepwise method applied for factor selection. Results differed according to the depth at which nutrient data were extracted. When nutrient data below the pycnocline (75-200 m) were used, better results (i.e. with higher 

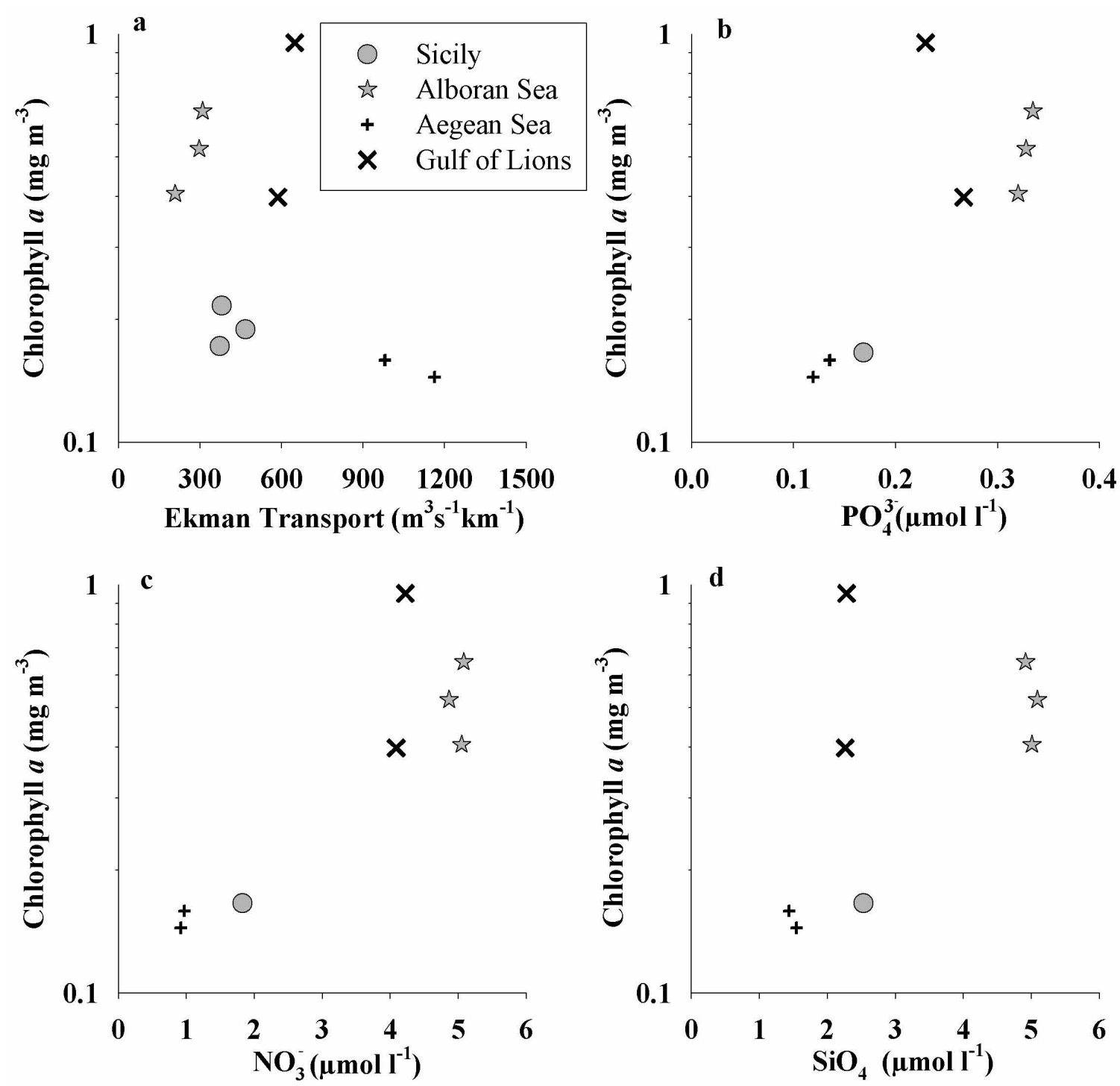

FIG. 9. - Climatological mean Chl $a$ vs offshore Ekman transport (a), phosphate concentration at the depth layer 75-200 m (b), nitrate concentration at depth layer 75-200 m (c), and silicate concentration at the depth layer 75-200 m (d) for the selected Mediterranean sites.

TABLE 2. - Statistical results of linear regression models relating Chl $a$ (regressand) and Ekman transport (ET), SST, stability, and windmixing index (regressors). For each geographical $1^{\circ} \times 1^{\circ}$ box of Figure $1-$ identified in the columns 1,2 , and 3 (coordinates refer to the centre of $1^{\circ} \times 1^{\circ}$ cells) - four linear models were fitted by regression between trend-removed monthly time series, one for each available regressor. For each model, Pearson's correlation coefficients (R) between regressors and regressand (Chl $a$ ) reported in column 7 represent the maximum absolute values obtained among tested regressions at lags 0,1 , and 2 (column 5), with degrees of freedom given in column 6. Column 8 indicates the significance of the observed correlation on the basis of Bonferroni correction (“*” $\mathrm{p}<0.05 / 36$; “**” $\mathrm{p}<0.01 / 36$; “***” $\mathrm{p}<0.001 / 36$ ). The critical p-value at the 0.05 significance level, with Bonferroni correction, is 0.001389 .

\begin{tabular}{|c|c|c|c|c|c|c|c|}
\hline $\begin{array}{l}1 \\
\text { Box }\end{array}$ & $\begin{array}{c}2 \\
\text { Lat N }\end{array}$ & $\begin{array}{c}3 \\
\text { Lon } \mathrm{E}\end{array}$ & $\begin{array}{c}4 \\
\text { Regressor }\end{array}$ & $\begin{array}{c}5 \\
\operatorname{lag}\end{array}$ & $\begin{array}{c}6 \\
\mathrm{df}\end{array}$ & $\begin{array}{l}7 \\
\mathrm{R}\end{array}$ & $\begin{array}{c}8 \\
\text { Significance }\end{array}$ \\
\hline 1 & 37.5 & 12.5 & ET & 2 & 120 & 0.28 & 0.0021 \\
\hline 2 & 37.0 & 13.5 & ET & 0 & 122 & 0.12 & 0.1979 \\
\hline 3 & 36.5 & 14.5 & ET & 1 & 121 & 0.12 & 0.1805 \\
\hline 1 & 37.5 & 12.5 & SST & 0 & 122 & -0.28 & 0.0019 \\
\hline 2 & 37.0 & 13.5 & SST & 0 & 122 & -0.25 & 0.0045 \\
\hline 3 & 36.5 & 14.5 & SST & 0 & 122 & -0.33 & $* *$ \\
\hline 1 & 37.5 & 12.5 & Stability & 0 & 122 & -0.06 & 0.5220 \\
\hline 2 & 37.0 & 13.5 & Stability & 0 & 122 & -0.06 & 0.4861 \\
\hline 3 & 36.5 & 14.5 & Stability & 1 & 121 & -0.21 & 0.0182 \\
\hline 1 & 37.5 & 12.5 & Wind-mixing index & 0 & 115 & 0.36 & $* *$ \\
\hline 2 & 37.0 & 13.5 & Wind-mixing index & 0 & 115 & 0.25 & 0.0067 \\
\hline 3 & 36.5 & 14.5 & Wind-mixing index & 0 & 115 & 0.27 & 0.0028 \\
\hline
\end{tabular}


$\mathrm{R}^{2}$ values) were obtained with a bivariate model including nitrate together with wind-mixing index, which explains $93.9 \%$ of the variance in $\ln (\mathrm{Chl} a)$ $\left(F_{2,5}=38.8, p=0.001\right)$. With nutrient data above the pycnocline the same backward stepwise procedure selected phosphate, silicate and wind-mixing index $\left(F_{34}\right.$ $\left.=125.7, \mathrm{p}<0.001 ; \mathrm{R}^{2}=0.99\right)$. It is worth noting that all the considered factors were positively correlated with Chl $a$ concentration.

\section{Correlation analysis between environmental factors and Chl $\boldsymbol{a}$ monthly time series}

The results of the linear regression analysis between detrended anomalies of Chl $a$ (regressand) and Ekman transport, SST, stability and wind-mixing index (regressors) are given in Table 2 . These show the Pearson correlation coefficients and related significance levels resulting from the adoption of Bonferroni correction for all linear regressions tested.

The relationship between Ekman transport and Chl $a$ was not significant. Conversely, a significant negative linear relationship between SST and Chl $a$ was detected at the easternmost box site. As expected, estimated $\mathrm{R}$ values were positive for Ekman transport and negative for SST, as the upwelling of nutrient-rich subsurface waters is related to a decrease in the surface temperature regime (see Fig. 2a). However, Chl $a$ showed a generally stronger relationship with SST compared with Ekman transport. Additionally, where $\mathrm{R}$ values for Ekman transport were lower, the $\mathrm{R}$ coefficients for SST were higher (in absolute value), with a decreasing eastward trend for Ekman transport and increasing eastward trend for SST.

Positive relationships with the wind-mixing index were also observed to occur, with a significant $\mathrm{R}$ value in one out of three geographical boxes. For water column stability, none of the estimated correlation coefficients was significantly different from zero.

\section{DISCUSSION}

Recently, Patti et al. (2008) showed that Ekman transport is one of the most important factors responsible for the differences in primary production observed among the main world EBUS regions. It is possible that the background low primary production in the $\mathrm{Si}$ cilian Channel is somewhat related to a reduced windinduced upwelling (Fig. 4c), which results in a low input of nutrients into surface layers (Fig. 8). However, the data showed that in the oligotrophic Mediterranean Sea, wind-induced coastal upwelling intensity alone is not able to justify the observed differences in Chl $a$ (Fig. 9a).

In the Mediterranean Sea the prevailing westerly winds produce offshore-directed Ekman transport and coastal upwelling off the southern sides of the bigger islands (Bakun and Agostini, 2001). Several authors have observed a frequent local occurrence of upwelling events for the south coast of Sicily, which is certainly associated with local winds (Piccioni et al., 1988; Lermusiaux, 1999; Robinson et al., 1999; Warn-Varnas et al., 1999; Molcard et al., 2002; Astraldi et al., 2002; Sorgente et al., 2003; Béranger et al., 2004). This upwelling regime is observed to occur off the southern coast of Sicily, whereas downwelling processes are expected to occur along the eastern coast of Tunisia on the opposite side of the Strait (Agostini and Bakun, 2002). However, south-eastward winds alone are not the only factor responsible for coastal upwelling, a persistent feature off the southern Sicilian coast. Surface circulation is controlled by the flow of modified Atlantic water (MAW), which is locally referred to as the Atlantic Ionian Stream (AIS) (Robinson et al., 1999). The AIS, when passing through the Sicilian Channel, produces two large cyclonic vortices, one over Adventure Bank and a second one off Cape Passero, at the southernmost tip of Sicily. The signature of the upwelling of subsurface cold waters associated with these vortices is visible in the averaged satellite SST (Fig. 2a). In addition, along the AIS trajectory a density front to the left of the current, facing downstream, is observed to occur. The AIS anticyclonic meander characterizing surface flow in the central part of the southern Sicilian coast determines the uprising of the underlying LIW to the surface, due to geostrophic adjustment processes (García Lafuente et al., 2002; Béranger et al., 2004). This also causes the fertilization of coastal waters, as also visible in averaged satellite Chl $a$ products (Fig. 2b). Furthermore, it is clear that also in the other Mediterranean coastal upwelling systems under study, offshore Ekman transport alone is not able to drive the input of nutrients into surface layers (Fig. 8). Locally, the enrichment processes are also due to other eventually more important mechanisms, such as the Rhone river outflow for the Gulf of Lions, responsible for $50 \%$ of the annual local primary production (Lochet and Leveau, 1990), the inflow of nutrient-enriched Atlantic surface waters and mesoscale activity for the Alboran Sea (Sarhan et al., 2000; Baldacci et al., 2001, Reul et al., 2005), and Black Sea water inflow through the Straits of Dardanelles for the Aegean Sea (Stergiou et al., 1997). It is worth noting that at approximately the same level of wind forcing, in the Alboran Sea and the Gulf of Lions nitrate and phosphate concentrations are approximately double those of the Sicilian Channel (where, in contrast, the silicate concentration levels are relatively high), while the very strong Ekman transport levels in the Aegean region are not able to produce Chl $a$ concentrations greater than those observed in the central Mediterranean area (see Fig. 8 and Table 1 ). The abovementioned processes also affect primary production and are probably responsible for the counterintuitive inverse relationship between Ekman transport and Chl $a$ observed in the Mediterranean coastal upwelling systems considered (Fig. 9a). Conversely, the importance of nutrient availability and water column mixing, independent of wind-induced upwelling, 
was emphasized by the results of the present work. Specifically, phosphate and silicate concentrations appeared to be critical in the surface layer, whereas below the pycnocline nitrate was more important.

In this general regime of low productivity in the Sicily channel due to low nutrient concentrations, another question concerns which physical factors may be considered as most responsible for the monthly modulation of primary production levels. This is exactly what was addressed by the correlation analysis carried out on the available environmental time series. The relatively low fraction of variance in Chl $a$ explained by Ekman transport (ET), the higher correlation values between $\mathrm{Chl} a$ and SST compared with ET, and the apparent inverse eastward pattern in the R coefficients for ET and SST factors (decreasing for ET and increasing for SST) would suggest the importance of general surface circulation and local topography in influencing the coastal upwelling and, through the related input of nutrients, the Chl $a$ levels off the southern coast of Sicily.

The analysis of linear trends characterizing the time series gives further insights. The SST has been subjected to a significant increasing trend $(p<0.001)$ over the last 30 years, with less significant but still important growth rates over the last decade, due to the intrinsic increased variability in monthly values. Conversely, stability did not show any significant increasing trend, even considering the longer time span of the SODA data (1958-2007). The same was observed to occur in the satellite-based Chl $a$. Therefore, the limiting mechanism for primary production which is related to the enhanced stratification processes resulting from the general warming trend of global open ocean (Behrenfeld et al., 2006), also suggested to occur in Mediterranean waters (Barale et al., 2008), is not active over most of the northern sector of the Sicilian Channel. Actually, in the context of a general decreasing Chl $a$ trend in Mediterranean waters, especially over the basin interior, it has been observed that some coastal areas follow an opposite tendency (Barale et al., 2008). On the basis of SeaWiFS data for the last decade, this appears to be the case in the near-coastal zones off the south Sicilian coast, at least over the two more westerly $1^{\circ} \times 1^{\circ}$ cells investigated in this study. Specifically, wind-induced and surface circulation-related processes operating there are believed to be able to compensate for the negative effects on primary production generated by the general warming trend of the surface waters, as recently observed in most EBUSs (Demarcq, 2009). In this context, correlation analysis clearly showed that Chl $a$ monthly changes are not driven by stratification, at least during the time span covered by the SeaWiFS mission (the last ten years). Indeed, the positive correlations between wind-mixing index and Chl $a$ observed during the last ten years would testify to the importance of wind-induced mixing processes as an explanation for Chl $a$ variation, independent of induced upwelling. These results do not support, at least for the coastal areas investigated, the hypothesis that a limiting mechanism for primary production is related to the enhanced stratification processes resulting from the general warming trend of Mediterranean waters.

\section{REFERENCES}

Agostini, V.N. and A. Bakun. - 2002. "Ocean triads" in the Mediterranean Sea: physical mechanisms potentially structuring reproductive habitat suitability (with example application to European anchovy, Engraulis encrasicolus). Fish. Oceanogr., 11: 129-142.

Astraldi, M., G.P. Gasparini, A. Vetrano and S. Vignudelli. - 2002. Hydrographic characteristics and interannual variability of water masses in the central Mediterranean: a sensitivity test for long-term changes in the Mediterranean Sea. Deep-Sea Res. I, 49: 661-680.

Bakun, A. - 1973. Coastal upwelling indices, west coast of North America. 1946-71. NOAA Tech. Rep. NMFS-671: 1-103.

Bakun, A. and V. Agostini. - 2001. Seasonal patterns of wind driven upwelling/downwelling in the Mediterranean Sea. Sci. Mar., 65: 243-257.

Baldacci, A., G. Corsini, R. Grasso, G. Manzella, J.T. Allen, P. Cipollini, T.H. Guymer and H.M. Snaith. - 2001. A study of the Alboran sea mesoscale system by means of empirical orthogonal function decomposition of satellite data. J. Mar. Syst., 29: 293-311.

Barale, V., J.-M. Jaquet and M. Ndiaye. - 2008. Algal blooming patterns and anomalies in the Mediterranean Sea as derived from the SeaWiFS data set (1998-2003). Remote Sens. Environ., 112: 3300-3313.

Basilone, G., C. Guisande, B. Patti, S. Mazzola, A. Cuttitta, A. Bonanno and A. Kallianiotis. - 2004. Linking habitat conditions and growth in the European anchovy (Engraulis encrasicolus). Fish. Res., 68: 9-19.

Behrenfeld, M.J., R.T. O’Malley, D.A. Siegel, C.R. McClain, J.L. Sarmiento, G.C. Feldman, A.J. Milligan, P.G. Falkowski, R.M. Letelier and E.S. Boss. - 2006. Climate-driven trends in contemporary ocean productivity. Nature, 444: 752-755.

Béranger, K., L. Mortier, G.P. Gasparini, L. Gervasio, M. Astraldi and M. Crépon. - 2004. The dynamics of the Sicily Strait: A comprehensive study from observations and models. Deep-Sea Res. II, 51: 411-440.

Boyer, T.P., J.I. Antonov, H.E. Garcia, D.R. Johnson, R.A. Locarnini, A.V. Mishonov, M.T. Pitcher, O.K. Baranova and I.V. Smolyar. - 2006. In: S. Levitus (ed.), World Ocean Database 2005. NOAA Atlas NESDIS 60, U.S. Government Printing Office, Washington, D.C., 190 p., DVDs.

Carr, M.E. - 2002. Estimation of potential productivity in Eastern Boundary Currents using remote sensing. Deep-Sea Res. II, 49: 59-80.

Carr, M.E. and E.J. Kearns. - 2003. Production regimes in four Eastern Boundary Current systems. Deep-Sea Res. II, 50: 3199-3221.

Carton JA, G. Chepurin, X. Cao and B. Giese. - 2000. A simple ocean data assimilation analysis of the global upper ocean 1950-95. J. Phys. Oceanogr. I, 30: 294-309.

Crispi, G. and M. Pacciaroni. - 2009. Long-term numerical evolution of the nitrogen bulk content in the Mediterranean Sea. Est. Coast Shelf Sci., 83: 148-158.

Demarcq, H. - 2009. Trends in primary production, sea surface temperature and wind in upwelling systems (1998-2007). Prog. Oceanogr., 83: 376-385.

Estrada, M. - 1996. Primary production in the northwestern Mediterranean. Sci. Mar., 60: 55-64.

Feldman, G.C. and C.R. McClain. - 2006. Ocean Color Web. SeaWiFS Reprocessing 5. In: N. Kuring and S.W. Bailey (eds.), NASA Goddard Space Flight Center., http://oceancolor.gsfc. nasa.gov/

Garcia, H.E., R.A. Locarnini, T.P. Boyer and J.I. Antonov. - 2006. World ocean atlas 2005, volume 4: nutrients (phosphate, nitrate, silicate). In: S. Levitus (ed.) NOAA Atlas NESDIS 64, pp. 1-396. U.S. Government Printing Office, Washington, D.C.

García-Lafluente, J., A. García, S. Mazzola, L. Quintanilla, J. Delgado, A. Cuttitta and B. Patti. - 2002. Hydrographic phenomena influencing early stages of the Sicilian Channel Anchovy. Fish. 
Oceanogr., 11: 31-44.

Guisande, C., J.M. Cabanas, A.R. Vergara and I. Riveiro. - 2001. Effect of climate on recruitment success of Atlantic Iberian sardine (Sardina pilchardus). Mar. Ecol. Prog. Ser., 223: 243-250

Guisande, C., A. Barreiro, I. Maneiro, I. Riveiro, A.R. Vergara and A. Vaamonde. - 2006. Tratamiento de datos. Díaz de Santos, Madrid.

Hardman-Mountford, N.J., A.J. Richarson, J.J. Agenbag, E. Hagen, L. Nykjaer, F.A. Shillington and C. Villacastin. - 2003. Ocean climate of the South East Atlantic observed from satellite data and wind models. Prog. Oceanogr., 59: 181-221.

Iverson, R.L. - 1990. Control of marine fish production. Limnol. Oceanogr., 35: 1593-1604.

Jennings, S., M.J. Kaiser and J.D. Reynolds, - 2001. Marine Fisheries Ecology. Blackwell Science, Oxford.

Joint, I. and S.B. Groom. - 2000. Estimation of phytoplankton production from space: Current status and future potential of satellite remote sensing. J. Exp. Mar. Biol. Ecol., 250: 233-255

Karafistan, A., J.-M. Martin, M. Rixen and J.M. Beckers. - 2002. Space and time distributions of phosphate in the Mediterranean Sea. Deep-Sea Res. I, 49: 67-82.

Lermusiaux, P.F.J. - 1999. Estimation and study of mesoscale variability in the strait of Sicily. Dynam. Atmosph. Oceans, 29: 255-303.

Lochet, F. and M. Leveau. - 1990. Transfers between a eutrophic ecosystem, the river Rhône, and an oligotrophic ecosystem, the north-western Mediterranean Sea. Hydrobiologia, 207: 95-103.

Miller, R.G. - 1981. Simultaneous Statistical Inference. 2nd ed. Springer Verlag, New York.

Molcard, A., L. Gervasio, A. Griffa, G.P. Gasparini, L. Mortier and T.M. Özgökmen. - 2002. Numerical investigation of the Sicily Channel dynamics: density currents and water mass advection. J. Mar. Syst., 36: 219-238.

Patti, B., C. Guisande, A.R. Vergara, I. Riveiro, I. Maniero, A. Barreiro, A. Bonanno, G. Buscaino, A. Cuttitta, G. Basilone and S. Mazzola. - 2008. Factors responsible for the differences in satellite-based chlorophyll $a$ concentration between the major global upwelling areas. Est. Coast. Shelf Sci., 76: 775-786.

Piccioni, A., M. Gabrielle, E. Salusti and E. Zambianchi - 1988. Wind-induced upwellings off the southern coast of Sicily. Oceanol. Acta, 11: 309-314.

Reul, A., V. Rodríguez, F. Jiménez-Gómez, J.M. Blanco, B. Bautista, T. Sarhan, F. Guerrero, J. Ruíz and J. García-Lafuente. - 2005. Variability in the spatio-temporal distribution and size-structure of phytoplankton across an upwelling area in the NW-Alboran Sea, (W-Mediterranean). Cont. Shelf Res., 25: 589-608.
Reynolds, R.W., N.A. Rayner, T.M. Smith, D.C. Stokes and W. Wang. - 2002. An improved in situ and satellite SST analysis for climate. J. Clim., 15: 1609-1625.

Ribeiro, A.C., A. Peliz and A.M.P. Santos. - 2005. A study of the response of chlorophyll- $a$ to a winter upwelling event off Western Iberian using SeaWiFS and in situ data. J. Mar. Syst., 53: 87-107.

Rykaczewski, R.R. and D.M. Checkley Jr. - 2008. Influence of ocean winds on the pelagic ecosystem in upwelling regions. Proc. Natl. Acad. Sci. USA, 105: 1965-1970.

Robinson, A.R., J. Sellschopp, A. Warn-Varnas, W.G. Leslie, C.J. Lozano, P.J. Haley Jr., L.A. Anderson and P.F.J. Lermusiaux. - 1999. The Atlantic Ionian Stream. J. Mar. Syst., 20: 129-156.

Sarhan, T., J. García Lafuente, M. Vargas, J.M. Vargas and F. Plaza. - 2000. Upwelling mechanisms in the northwestern Alboran Sea. J. Mar. Syst., 23: 317-331.

Schlitzer, R. - 2008. Ocean Data View. http://odv.awi.de

Sorgente, R., A.F. Drago and A. Ribotti - 2003. Seasonal variability in the Central Mediterranean Sea circulation. Ann. Geophys., 21: $299-322$.

StatSoft, Inc. - 2001. STATISTICA (data analysis software system), version 6. www.statsoft.com.

Stergiou, K.I., E.D. Christou, D. Gergopoulos, A. Zenetos and C. Souvermezoglou. - 1997. The Hellenic seas: physics, chemistry, biology and fisheries. Oceanogr. Mar. Biol. Annu. Rev. 35: 415-538.

Thomas, A.C, P. Strub, F. Huang and C. James. - 1994. A comparison of the seasonal and interannual variability of phytoplankton pigment concentrations in the Peru and California Current System. J. Geophys. Res. 99: 7355-7370.

Thomas, A.C., Strub, P.T., Carr, M.E. and Weatherbee, R. - 2004. Comparison of chlorophyll variability between the four major global eastern boundary currents. Int. J. Remote Sens., 25: 1443-1447.

Warn-Varnas, A., J. Sellschopp, P.J. Haley Jr., W.G. Leslie and C.J. Lozano. - 1999. Strait of Sicily water masses. Dynam. Atmosph. Oceans, 29: 437-469.

Ware, D.M. - 1992. Production characteristics of upwelling systems and the trophodynamic role of hake. In: A.I. Payne, K.H. Brink, K.H. Mann, and R. Hilborn (eds.), Benguela Trophic Functioning. S. Afr. J. Mar. Sci., 12: 501-513.

Scient. ed.: M. Estrada.

Received July 3, 2009. Accepted December 22, 2009.

Published online May 28, 2010. 